\title{
Working
}

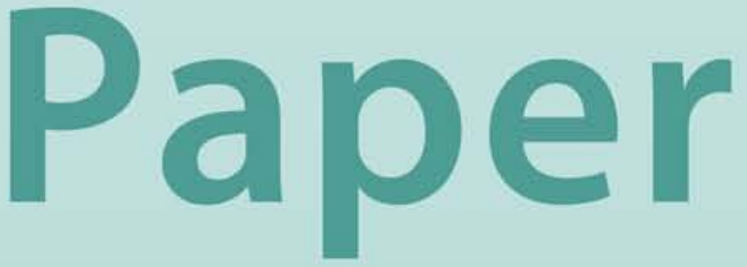


Bankruptcy and Firm Dynamics: The Case of the Missing Firms

José Daniel Rodríguez-Delgado 


\title{
IMF Working Paper
}

\author{
IMF Institute
}

\section{Bankruptcy and Firm Dynamics: The Case of the Missing Firms}

\section{Prepared by José Daniel Rodríguez-Delgado ${ }^{1}$}

Authorized for distribution by Jorge Roldós

February 2010

\begin{abstract}
This Working Paper should not be reported as representing the views of the IMF. The views expressed in this Working Paper are those of the author(s) and do not necessarily represent those of the IMF or IMF policy. Working Papers describe research in progress by the author(s) and are published to elicit comments and to further debate.
\end{abstract}

Financial frictions have been documented as an important determinant of firm dynamics. In this paper I model bankruptcy procedures, liquidation in particular, as an institutional feature that affects both sides of financial transactions. I construct a model of firm dynamics that generate endogenous borrowing limits and I find that a) inefficient bankruptcy procedures can have quantitatively important aggregate effects, but more importantly; b) that such effects would not be directly visible in the firms that industrial censuses and surveys focus on. I conclude that to capture the effects of the legal framework we need to look beyond the existing firms.

JEL Classification Numbers: G11, G33, L16, L25

Keywords: Bankruptcy, firm dynamics, financial constraints.

Author’s E-Mail Address: jrodriguezdelgado@imf.org

\footnotetext{
${ }^{1}$ Mr. Rodríguez-Delgado is an Economist in the Western Hemisphere Division of the IMF Institute. I thank Timothy J. Kehoe and Cristina Arellano for their constant encouragement and advice. Jose Victor Rios-Rull, Martin Schneider, Fabrizio Perri, Erem Atesagaoglu, Alma Romero-Barrutieta and Murat Seker provided many useful suggestions. Maria Julia Gutierrez provided excellent editorial assistance. The usual disclaimer applies
} 


\section{Contents}

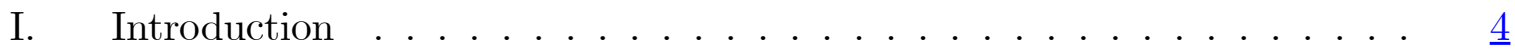

II. Related Literature . . . . . . . . . . . . . . . . . $\underline{4}$

III. Model Economy . . . . . . . . . . . . . . . . . . . $\underline{6}$

A. Legal Framework ................. . . . . . $\underline{7}$

B. Firm's Problem ................. $\underline{8}$

1. Existing Project ................. $\underline{8}$

2. New Projects . . . . . . . . . . . . . . . 10

C. Financial Contracts . . . . . . . . . . . . . . 10

D. Equilibrium . . . . . . . . . . . . . . . . 11

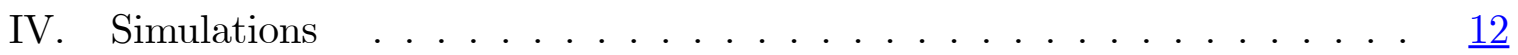

A. Calibration ................... . . 12

1. Bankruptcy Efficiency .............. . . . $\underline{12}$

2. Entry and Exit Statistics ............ . . . . . 13

B. Benchmark Model . . . . . . . . . . . . . . . . . $\underline{15}$

1. Firm's Decision to Liquidate . . . . . . . . . . . $\underline{15}$

2. Bond Price Schedule . . . . . . . . . . . . . . . . $\underline{15}$

3. Firm Dynamics . . . . . . . . . . . . . . . 16

C. Comparative Statics . . . . . . . . . . . . . . . $\underline{16}$

1. Bond Price Schedules . . . . . . . . . . . . . . . 16

2. Firm Dynamics . . . . . . . . . . . . . . . . . . . 17

3. Aggregate Statistics . . . . . . . . . . . . . 17

V. Concluding Remarks . . . . . . . . . . . . . . . . . 19

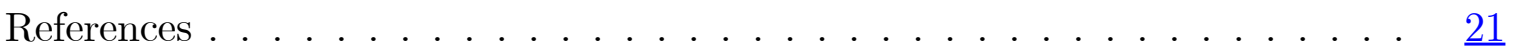

Appendix Table A.1 Bankruptcy Efficiency for OECD Members . . . . . . . $\underline{23}$

Tables

1. Bankruptcy Efficiency and Financial Constraints . . . . . . . . . . $\underline{24}$

2. Parameter Values . . . . . . . . . . . . . . . . . . 24

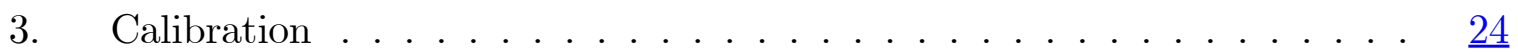

4. Comparative Statics . . . . . . . . . . . . . . . $\underline{25}$

5. Bankruptcy Efficiency and Financial Frictions . . . . . . . . . . . $\underline{25}$

Figures

1. Liquidation Decision, Average Productivity ........... $\underline{26}$

2. Liquidation Decision, High productivity Productivity . . . . . . . . $\underline{26}$

3. Bond Prices for Large and Small Firms . . . . . . . . . . . . . . $\underline{27}$ 
4. Effective Financing for Large and Small Firms . . . . . . . . . . . . $\underline{27}$

5. Firm Dynamics Benchmark and First Best . . . . . . . . . . . . $\underline{28}$

6. Effective Financing and Bankruptcy Efficiency . . . . . . . . . . . $\underline{28}$

7. Firm Dynamics and Bankruptcy Efficiency . . . . . . . . . . . . . . $\underline{29}$

8. Entrants Productivity Distribution . . . . . . . . . . . . . . $\underline{29}$

9. Firm Size Distribution and Bankruptcy Efficiency . . . . . . . . . . $\underline{30}$ 


\section{Introduction}

Financial frictions have been documented to be an important factor behind the evolution of firms across the world. Within the theoretical strand of the literature, enforcement and information problems are now standard ways to rationalize the presence of such frictions. On the other hand, recently compiled cross-country indexes of legal and institutional development (e.g. Djankov, et al., 2006) have shed light on the particular legal areas that firms find most obstructive to their growth plans. In this paper I focus on a particular legal feature, the procedures followed after liquidation, to disentangle the effects that weak or inefficient procedures could have on the ability of firms to finance their operations, to grow and to recover from shocks.

At any point in time, a significant fraction of firms fail to remain profitable and exit the market. The subject of study of this paper is the process followed after such exit. I construct a model that provides a quantitative laboratory to evaluate the effects that the ability of such process to transfer the liquidated assets from the firm to the lender (its efficiency) has not only on the exiting firms, but also on any other firm looking for financing. The framework is one of complete enforcement and perfect information so that lenders will, when lending money, forecast the probability that a given firm will not pay and, if default were to occur, the fraction of assets it would collect. On a conceptual basis, I merge the recent literature on sovereign default (e.g. Arellano, 2008) with the canonical analysis of firm dynamics (e.g. Hopenhayn, 1992), to build a model in which differences in the bankruptcy procedures can be mapped directly into the financial transactions and consequently in the overall industrial structure. The model combines both the market incompleteness and the role of default probabilities in determining the individualized financial contracts a lender offers, with a standard dynamic model of firm's investment and production decisions. In the simulations, the model is calibrated to match firm entry and exit statistics of the Mexican manufacturing sector.

My findings are as follows: a) inefficient bankruptcy procedures can have quantitatively important effects on the aggregate level of output, but more importantly, b) such effects would not be directly visible in the firms that industrial censuses and surveys focus on. The inefficiency would hurt the entry process the most, that is, it would limit the set of active projects undertaken in the economy. I conclude that to fully understand the role of the legal framework in the evolution of firms we need to look beyond the characteristics of the existing firms.

\section{Related Literature}

The literature dealing with firms' financial (borrowing) constraints includes several empirical studies that, by discovering deviations from the frictionless neoclassical 
framework, point toward promising modifications of the basic model that could better reflect actual conditions. The existence of frictions is generally accepted; their quantitative role is still an open research field (Hubbard, 1998).

Empirical findings have also highlighted the need for richer structural models that could rationalize the existence of financial constraints and their implications on firms' evolution. In an early attempt Cooley and Quadrini (2001) explore the interdependence of persistent productivity shocks with asymmetric information in explaining the conditional correlations among size and age within an incomplete markets environment. In more recent developments, Albuquerque and Hopenhayn (2004) put forward the lack of commitment as an important mechanism behind underinvestment, early termination and the absolute lack of financing for some projects. In their derivation of the optimal contingent contract between a lender and a given firm, they point toward the need to understand that borrowing constraints are not exogenous or static, but that they are derived from the lender's expectations of future periods in which the financial friction binds. Cooley, Marimon and Quadrini (2004) extend the analysis to derive aggregate implications; they show how the presence of incomplete enforcement rationalizes both the amplification of aggregate temporary shocks and the slow response to aggregate permanent shocks. Clementi and Hopenhayn (2006) provide an alternative rationale behind borrowing constraints: asymmetric information between the lender and the firm. An important feature of both Clementi and Hopenhayn (2006) and Albuquerque and Hopenhayn (2004) is the derivation of the optimal contingent contract; in contrast, in this paper I derive endogenous borrowing constraints under incomplete markets and assuming perfect information and complete enforcement.

This paper also relates to the literature studying the legal framework as a determinant of financial development and economic activity in aggregate as well as at the firm level. Levine (1998) employs indicators of contract enforcement and the protection of creditor rights, that is, "the ability of banks to persuade firms to pay their loans", to explain financial development (credit assigned to the private sector as a fraction of GDP). He finds both that cross-country variation in such legal metrics explains more than half of the variation in financial development and that financial development is an important determinant of economic growth. At the firm level, Beck, Demirguc-Kunt and Levine (2005), find that the adaptability of the legal system, "the extent to which judicial decisions are sources of law and whether judicial processes are based on principles of equity rather than purely on statutory law and legal formalities", is an important determinant of the obstacles firms face when obtaining financing.

Furthermore, The World Business Environment Survey, a multi-country firm-level survey that asks firms how financial, legal or corruption-related issues restrict their operations and growth plans, has helped advance the research agenda in this area. Beck, Demirguc-Kunt, Maksimovic (2005) find that if these responses were combined with actual firm growth data, a clear pattern emerged: small firms are affected the most (see also Beck, et al., 2007). They also find that obstacles rated 
highest by the firms themselves did not necessarily appear as the most significant in their statistical analysis. In terms of the indicators of the legal framework they conclude that the "...mechanism by which the legal system affects firm performance is not yet well understood." In this paper I attempt to help disentangle the connection between the legal framework and the evolution (entry, exit, growth) of firms by focusing on one of its elements, the liquidation process.

A third strand of literature related to this paper studies firms' investment patterns to infer the presence of borrowing constraints using reduced form representation of financial frictions. Bayer (2006) and Whited (2006) are two recent examples. Whited (2006) targets the discrete choice of starting large investment projects when the firm combines costly external financing (equity) with internal savings. He imposes a cost function of issuing equity as a reduced form representation of information frictions. Bayer (2006) extends the analysis to also tackle the intensive margin of investment while assuming both that the firm has no access to equity and that borrowing is limited such that bankruptcy never occurs. In his model, interest rate is assumed to be a function of the debt/assets ratio. In this paper I contribute to this literature by deriving the interest rate premium and borrowing constraints from fundamentals.

The effects of bankruptcy procedures on firms were analyzed by Davydenko and Franks (2006) where they compare the creditor's reaction to firms that defaulted in France, Germany and the UK. They find "that large differences in creditors' rights across countries lead banks to adjust their lending and reorganization practices..." Furthermore, they document that despite such adjustments, recovery rates vary substantially. As my model shows, the distortions of bankruptcy laws are not exclusive to the firms undergoing liquidation. In the lifetime of a given firm, the financing options it receives would be more limited the more inefficient the bankruptcy procedure is notwithstanding it may never file for liquidation itself. In the model I develop below, the determination of firms' bankruptcy decision becomes central to the analysis. Uhrig-Homburg (2005) also emphasizes the endogenous determination of such bankruptcy decision. She deals explicitly with both cash-flow shortages and overindebtedness as determinants of bankruptcy and derives credit spreads and debt levels using a partial equilibrium approach in which both firm's assets value and the ongoing cash flows are exogenous.

\section{Model Economy}

The economy is populated by a unit mass of risk neutral entrepreneurs and by competitive and risk-neutral lenders and it is similar to the framework in Arellano, Bai and Zhang (2007). Each entrepreneur is either operating a single project or idle. Entrepreneurs become idle if: 1) in the previous period they filed for bankruptcy or,

2 ) in the previous period they were idle but failed to start a new project. In particular, all entrepreneurs who file for bankruptcy or fail to start a new project 
die and new idle entrepreneurs are born to replace them. When idle, entrepreneurs can costlessly draw a new project. Moreover, entrepreneurs face an outside option whose value is normalized to zero. Given these assumptions, I will characterize the economy as being populated by projects or firms whenever there is no risk of confusion.

When just started, projects are characterized by their initial productivity level $z$ that follows a stochastic process; each entrepreneur maximizes the expected value of the project's dividends through borrowing and the accumulation of capital subject to the available financing opportunities. Therefore, during their evolution projects are characterized by their capital stock $k$, debt holdings $b$, and productivity level $z$ summarized in $x=(k, b, z)$.

Projects face two sources of uncertainty: 1) their productivity level is governed by a Markov process $Q\left(z^{\prime} \mid z\right)$ and 2) their capital stock is potentially depleted by disruption shocks; with probability $\tau$ they would start the next period with zero physical assets. The latter feature is meant to capture the probability of strikes, natural disasters, or capital obsolescence and, as it will be explained below, has a close resemblance to the standard way of modelling exogenous exit rate. It could be useful to think of a project with $k>0$ as a firm; on the other hand, a project with $k=0$ could be thought of as a start-up waiting to be financed or a currently existing firm that lost its assets and could potentially reemerge. I will focus on the stationary equilibrium of this model where the central object of analysis is the distribution of projects that become active.

The only available financial instruments are loan contracts. Although loans can be made contingent on all the firms' current characteristics, they still represent an incomplete markets environment given that they cannot be made contingent on the next period's shocks. The environment is one of complete enforcement and perfect information. A central feature of the model is that both sources of uncertainty faced by the firms will be considered by the lenders when computing the likelihood of bankruptcy and therefore, when determining the corresponding interest rate charged $\left(1 / q\left(x, b^{\prime}\right)-1\right)$ on a given loan of size $b^{\prime}$ as well.

\section{A. Legal Framework}

Bankruptcy laws are complex mechanisms and vary considerably across countries (see Hart, 2000 and Frank and Sussman, 2005) so that in order to present a tractable framework I make several simplifying assumptions. The legal framework is as follows:

1. When a firm $x=(k, b, z)$ files for bankruptcy it ceases operations and it exits the market irreversibly. The firm is then classified as solvent, if $k \geq b$ or as insolvent if $k<b$. In the case of a solvent firm, the lender receives its regular 
payment and the firm keeps the difference $k-b$. We denote this first case as $S$ (scrap value). In the second scenario, formal bankruptcy procedures are started, denoted as $L$ (liquidation).

2. Bankruptcy procedures involve costs in terms of legal fees and/or in terms of the time involved to satisfy all the legal requirements. We model these costs as an iceberg cost $\mu$ that represents the fraction of capital lost during this process.

In this context, I characterize bankruptcy procedures by their efficiency in transferring the borrower's assets to the lender; the fraction of assets $(1-\mu)$ that survive the procedures. I further define the firm's value of filing for bankruptcy as:

$$
B K U(x)=\max (k-b, 0)
$$

Some remarks are in order. First, in this setup the lender will never seize assets of higher value than the existing debt. I also implicitly assume that the bank or lender cannot operate the firm and that it has the only option of selling the assets. ${ }^{1} \mathrm{~A}$ second important assumption is that each firm deals with one lender only. The coordination among the different classes of creditors (secured, senior, preferred, etc.) is undoubtedly a relevant factor in analyzing modern bankruptcy procedures. This paper provides a simple framework that could eventually be enriched with such features. Finally, the equation in (1) also reflects that in the model the entrepreneur's liability is limited by the size of his project's physical assets.

\section{B. Firm's Problem}

This section describes the firm's basic problem, taking as given the bond price schedule $q\left(x, b^{\prime}\right)$ that would be subsequently derived from the lender's optimality condition. I also assume that firms do not have access to equity financing and that they do not save. ${ }^{2}$ In this section, I first present the problem for an existing firm followed by the problem faced by an entrepreneur drawing a new project.

\section{Existing Project}

Each firm has access to the decreasing returns to scale technology $z k^{a}, 0<\alpha<1$ provided it covers the fixed costs of operations $f$ that captures, in a reduced form,

\footnotetext{
${ }^{1}$ Hennessy and Whited (2007) present a model in which the lender takes posession of the operating firms and may decide to re-finance the firm adjusting its equity value.

${ }^{2}$ See Arellano, Bai and Zhang (2007) for an example of the combination of equity and defaultable debt. Not allowing savings is for technical reasons only. It is also common to assume that the discount factor of the risk-neutral firms to be such that they prefer dividends today (cf. Bayer, 2006).
} 
entry and regulation costs and working capital requirements. Capital is depreciated at rate $\delta$ and dividends are discounted by $\beta$. After the realization of the current period's shock $z$ and having in possession capital $k$ and existing debt level $b$, the firm decides whether to file for bankruptcy or to pay and continue its operations. If it decides to pay, the firm then chooses its investment level $\left(k^{\prime}-(1-\delta) k\right)$ and debt contract $\left(q\left(x, b^{\prime}\right), b^{\prime}\right)$ from the menu of contracts being offered.

$$
\begin{gathered}
V(x=(k, b, z))=\max \{\operatorname{Pay}(x), B K U(x)\} \\
\operatorname{Pay}(x)=\max _{k^{\prime}, b^{\prime}} z k^{\alpha}+(1-\delta) k-k^{\prime}-b+q\left(x, b^{\prime}\right) b^{\prime}-f \\
+\beta E\left[(1-\tau) V\left(k^{\prime}, b^{\prime}, z^{\prime}\right)+\tau V\left(0, b^{\prime}, z^{\prime}\right) \mid z\right] \\
\text { subject to: } \\
\left(k^{\prime}, b^{\prime}\right) \in B(x)=\left\{(\tilde{k}, \tilde{b}) \mid z k^{\alpha}+(1-\delta) k-\tilde{k}-b+q(x, \tilde{b}) \tilde{b}-f \geq 0\right\}
\end{gathered}
$$

The expression in (2) represents the recursive representation of the firm's problem. The value of paying the existing debt is derived in (3) where the two sources of uncertainty are made explicit: the stochastic productivity shock and the possibility of facing a disruption shock. The set defined in (4) describes the fact that each firm must finance its investment and both the fixed cost and the payment of the existing debt out of its operating income $z k^{a}$ or by obtaining new financing $q\left(x, b^{\prime}\right) b^{\prime}$.

There are two basic reasons for a firm to file for bankruptcy: 1) the set of available capital and debt pairs could be empty, $B(x)=\varnothing$ in which case we set $\operatorname{Pay}(x)=-\infty$, or 2) the combination of productivity level and debt holdings could make physical assets more valuable if they were sold rather than used in production, $k-b>\operatorname{Pay}(x)$. In all the simulations presented in this paper this second possibility was, for all practical purposes, absent.

Along their evolution, firms face the fundamental trade-off of borrowing to increase their production capacity according to their productivity level, while facing the possibility of receiving a detrimental shock in the next period and failing to cover the fixed cost. Firms value capital not only because of its capacity to generate dividends in the next period but also because they would relax next period's financial constraint. As the firms increase in size the financial constraint becomes less important and they eventually behave as unrestricted.

The solution of the firm's problem generates its capital and debt policy functions $g^{k}(x), g^{b}(x)$ as well as its optimal decision rule $g^{d}(x)$, which describes if the firm decides to file for liquidation either as solvent or insolvent. In particular, $g^{d}(x)$ takes on three values $\{P, S, L\}$ corresponding to Pay, Scrap (file while being solvent) and Liquidate respectively. 


\section{New Projects}

An idle entrepreneur faces the draw or birth of a new project drawn from $Q^{\infty}(z)$. $\mathrm{He} /$ she will then face the challenge to cover the fixed cost and the initial level of investment exclusively from new borrowing as in (5). If the entrepreneur fails to obtain enough financing he/she will enjoy the outside option valued at zero. From (2) and (5) it follows that $V^{e}(z)=V(x=(0,0, z))$ so in order to economize on notation, I will use $V(x)$ and $g^{k}(x), g^{b}(x), g^{d}(x)$ to describe the solution of both problems. $^{3}$

$$
\begin{gathered}
V^{e}(z)=\max \{\operatorname{Continue}(x=(0,0, z), 0\} \\
\operatorname{Continue}(x)=\max _{k^{\prime}, b^{\prime}}-k^{\prime}+q\left(x=(0,0, z), b^{\prime}\right) b^{\prime}-f \\
+\beta E\left[(1-\tau) V\left(k^{\prime}, b^{\prime}, z^{\prime}\right)+\tau V\left(0, b^{\prime}, z^{\prime}\right) \mid z\right] \\
\text { subject to: } \\
\left.-k^{\prime}+q\left(x, b^{\prime}\right) b^{\prime}-f \geq 0\right\}
\end{gathered}
$$

\section{Financial Contracts}

The loans are given by risk neutral, competitive lenders so that in equilibrium they offer loans that will give them zero expected profits. The loan contracts are pairs $\left(q\left(x, b^{\prime}\right), b^{\prime}\right)$ that specify the amount of money the firm receives today $q\left(x, b^{\prime}\right) b^{\prime}$ in exchange for paying back $b^{\prime}$ tomorrow, provided it does not file for bankruptcy. The implicit interest rate charged on a loan of $b^{\prime}$ becomes $\left(1 / q\left(x, b^{\prime}\right)-1\right)$. Each lender is able to observe all the firm's characteristics $x=(k, b, z)$ and it can charge different interest rates according to the firm's physical assets, current debt holdings and/or productivity level.

For each firm and loan size, the lenders compute the expected payment for the next period. If the firm decides to continue or exit while being solvent the lender will recover $b^{\prime}$. If instead, the firm files for liquidation the lender will receive the capital the firm would have net of the iceberg cost. In the (rational expectations) equilibrium each lender will correctly anticipate the capital level using the firm's capital policy function $g^{k}(x)$. Using the firm's policy functions the probability that the lender receives $b^{\prime}$ from a firm $x$ becomes: ${ }^{4}$

\footnotetext{
${ }^{3}$ In particular, $B K U(x=(0,0, z))=0$

${ }^{4} \mathrm{I}$ use $\chi$ to denote the indicator function. So that $\chi$ (Condition) takes value of 1 when the Condition is met and zero otherwise.
} 


$$
\begin{aligned}
A^{P}\left(x, b^{\prime}\right)= & (1-\tau) \int \chi\left(g^{d}\left(g^{k}(x), b^{\prime}, z^{\prime}\right) \in\{P, S\}\right) Q\left(z^{\prime} \mid z\right) d z^{\prime}+ \\
& \tau \int \chi\left(g^{d}\left(0, b^{\prime}, z^{\prime}\right) \in\{P, S\}\right) Q\left(z^{\prime} \mid z\right) d z^{\prime}
\end{aligned}
$$

The first term in (8) reflects the probability of repayment of a firm that does not suffer the disruption shock while the second term represents the corresponding repayment probability of a firm that arrives next period with its capital stock depleted.

Analogously, the probability that the firm would file for liquidation while holding positive $\operatorname{assets}^{5}$ is represented by:

$$
\begin{aligned}
A^{L}\left(x, b^{\prime}\right) & =(1-\tau) \int \chi\left(g^{d}\left(x^{\prime}\right)=L\right) Q\left(z^{\prime} \mid z\right) d z^{\prime} \\
& =(1-\tau) \int \chi\left(g^{d}\left(g^{k}(x), b^{\prime}, z^{\prime}\right)=L\right) Q\left(z^{\prime} \mid z\right) d z^{\prime}
\end{aligned}
$$

Therefore, the zero profit condition implicitly defines the bond price schedule as:

$$
q\left(x, b^{\prime}\right) b^{\prime}=\frac{A^{P}\left(x, b^{\prime}\right) b^{\prime}+A^{L}\left(x, b^{\prime}\right)(1-\mu) g^{k}(x)}{(1+r)}
$$

\section{Equilibrium}

I restrict my attention to stationary equilibria and, as it is standard in incomplete market models, I assume $\beta<(1 /(1+r))$. While the financial side of the equilibrium is summarized by equations ( 8 and 9 ), the characteristics of the real side of this economy are summarized by the distribution of firms across $x, \psi(x)$.

Definition. A stationary equilibrium consists of an invariant distribution $\psi(x)$ over the set of firms; a value function and policy functions $\left\{V(x), g^{k}(x), g^{b}(x), g^{d}(x)\right\}$, payment and liquidation sets $\left\{A^{P}\left(x, b^{\prime}\right), A^{L}\left(x, b^{\prime}\right)\right\}$ and a bond price schedule $q\left(x, b^{\prime}\right)$ such that

1. Given the bond prices schedule $q\left(x, b^{\prime}\right),\left\{V(x), g^{k}(x), g^{b}(x), g^{d}(x)\right\}$ solve the firm's problem (2)

\footnotetext{
${ }^{5}$ The case of a firm with no physical assets choosing to file for liquidation is of no interest for the lender.
} 
2. $\left\{A^{P}\left(x, b^{\prime}\right), A^{L}\left(x, b^{\prime}\right)\right\}$ are derived from $\left\{g^{k}(x), g^{b}(x), g^{d}(x)\right\}$ as in equations (8) and $(9)$

3. Given $\left\{A^{P}\left(x, b^{\prime}\right), A^{L}\left(x, b^{\prime}\right)\right\}$ and $\left\{g^{k}(x), g^{d}(x)\right\}, q\left(x, b^{\prime}\right)$ is such that the lenders make zero expected profits (10).

4. The invariant distribution $\psi(x)$ is derived from $Q\left(z^{\prime} \mid z\right)$ and $\left\{g^{k}(x), g^{b}(x), g^{d}(x)\right\}$ where in particular, new projects are drawn from the invariant distribution of $Q\left(z^{\prime} \mid z\right)$ that is, $Q^{\infty}(z)$

\section{Simulations}

\section{A. Calibration}

The model is solved numerically using a nested fixed point algorithm (see equation (11)) . In the 'inside loop', for a given $q_{0}\left(x, b^{\prime}\right)$ I solve the firm's problem by using the value function iteration method. This step generates $A^{P}\left(x, b^{\prime} \mid q_{0}\right), A^{L}\left(x, b^{\prime} \mid q_{0}\right)$ and $g^{k}\left(x \mid q_{0}\right)$. In the 'outside loop' equation (10) is checked and, in case it is not satisfied, a new guess $q_{1}\left(x, b^{\prime}\right)$ is constructed. As a final step, the invariant distribution is computed from the transition matrix that summarizes the likelihood of all the possible paths $x=(k, b, z) \rightarrow x^{\prime}=\left(k^{\prime}, b^{\prime}, z^{\prime}\right)$.

$$
q\left(x, b^{\prime}\right) b^{\prime}=\frac{A^{P}\left(x, b^{\prime} \mid q\right) b^{\prime}+A^{L}\left(x, b^{\prime} \mid q\right)(1-\mu) g^{k}(x \mid q)}{(1+r)}
$$

I calibrated the benchmark model to roughly match some key firm dynamic statistics of the Mexican manufacturing sector (from Bertelasman, Haltiwanger and Scarpetta, 2004) and using data from Djankov, et al. (2006) to estimate the liquidation efficiency in Mexico. I then performed comparative statics changing the level of efficiency to illustrate its effects both on aggregate output and on individual firm's characteristics.

\section{Bankruptcy Efficiency}

In this paper, I build on recent estimates constructed by Djankov, et al. (2006) that are available through the World Bank's Closing a Business Database (World Bank, 2007). The authors presented insolvency practitioners of several countries with an identical case of debt default and they asked them to describe the legal steps to be followed. Using the responses from each country's experts they constructed measures of the time, cost and the final disposition of the assets (e.g. preservation as 
going concern or piecemeal sale). Consistent with the simple legal framework in the model, I combined two of such indicators to construct an overall efficiency ${ }^{6}$ measure.

1. Years that takes to complete the bankruptcy procedures, $J$.

2. Cost as fraction of the estate that the bankruptcy procedures involve, $\lambda$

$$
(1-\mu)=(1-\lambda)\left(\frac{1}{1+r}\right)^{J}
$$

The database includes both indicators for more than 160 countries. For illustration purposes, I present here the estimates computed using equation (12) for a subsample that includes OECD members (see Appendix Table for full list of OECD members) and the country that ranked lowest in the bankruptcy efficiency indicator. There are two main lessons to be obtained from these numbers: 1) even among relatively developed countries-OECD members-there is significant variation in the fraction of assets lost during the bankruptcy procedures and; 2) the difference between the countries with the more inefficient bankruptcy procedures and developed countries is substantial. Table 1 also includes results from the WBES survey that "asked managers to rate the extent to which financing, legal, and corruption problems presented obstacles to the operation and growth of their businesses"(Beck, Demirguc-Kunt, Maksimovic, 2005). Managers selected a number between 1 and 4, where higher values indicate greater obstacles. The correlation between bankruptcy efficiency and financial and legal obstacles is statistically significant and positive; that is, in countries where the bankruptcy procedure takes longer or destroys a larger value of the estate, firms find greater financial and legal obstacles.

\section{Entry and Exit Statistics}

Given the structure of the model, standard entry and exit statistics cannot be used without first performing some adjustments. The goal is to make comparable measurements taken in the Model Economy to the ones performed in the real-world. The central issue is that a firm in the model exists regardless of having capital stock while in the data, such firms would not be measured given the standard thresholds of the typical industrial census.

\footnotetext{
${ }^{6}$ My definition of efficiency is different than the one used in Djankov, et al. (2006) that is centered in whether the defaulting firm is correctly identified as going concern or piecemeal sale.
} 


$$
\begin{aligned}
& \text { Entry }=\int \chi\left(k=0, g^{k}(x)>0\right) \psi(x) d x \\
& \text { Exit }=\int \chi\left(k>0, g^{d}(x) \neq P\right) \psi(x) d x \\
& +\tau \int \chi\left(k>0, g^{d}(x)=P\right) \psi(x) d x \\
& \text { Incumbents }=\int \chi(k>0) \psi(x) d x \\
& \text { where } d x \text { stands for }(d k, d b, d z)
\end{aligned}
$$

Entrants (13) include all firms that with zero capital today managed to obtain financing and then, provided they are not hit by the disruption shock, will appear with positive assets tomorrow. I consider their size to be $g^{k}(x)$, that is, the amount of capital they would possess in the next period. The mass of firms that exit the market is composed of two separate groups: 1) the first line (14) represents the endogenous exit component, firms that decide to file for bankruptcy and 2) the firms that decide to keep operating today but that are hit by the disruption shock and then would appear as having zero assets tomorrow (15). The latter is equivalent to the standard assumption of exogenous exit or death. I compute entry and exit rates relative to the mass of incumbents (16).

Tables 2 and 3 present the values used in the benchmark model. The technology parameter $\alpha$, the discount factor $\beta$, the depreciation rate $\delta$ and the interest rate $r$ were taken from standard values in the macro literature with the only goal to provide plausible parameters for the Mexican economy. The stochastic process is assumed to be log-normal distributed (17) and discretized using an 11-state Markov chain as in Heer and Maußner (2005). Such process is characterized by its autocorrelation $\rho_{z}$ and standard deviation parameters $\sigma_{z}$. For technical reasons I selected an autocorrelation coefficient somewhat lower than recent estimates $(0.53$ in Whited (2006)); several experiments using higher values gave equivalent results. ${ }^{7}$ The variance of the productivity shock is calibrated to roughly match the average exit rate on Mexico's manufacturing sector as reported by Bertelasman, Haltiwanger and Scarpetta (2004). The fixed cost is calibrated to match the relative size of entrants-ratio of average entrant size to average incumbent size as defined in (13) and (16). The resulting value of 0.3 is equivalent to $9.6 \%$ of the average firm size (see Table 3). Finally, the disruption shock is taken from Cooley, Marimon and Quadrini (2004).

$$
\ln \left(z^{\prime}\right)=\rho_{z} \ln (z)+\varepsilon, \varepsilon \sim N\left(0, \sigma_{\epsilon}\right)
$$

\footnotetext{
${ }^{7}$ In the computations, that used finite grids, a higher autocorrelation coefficient impacted the capital policy functions in such a way that a wider grid of capital values was required. To make the calibration more manageable, I lowered this value to ensure the predefined grids were not binding for any of the parameter values.
} 


\section{B. Benchmark Model}

\section{Firm's Decision to Liquidate}

The mechanism of the model generates a set of bankruptcy thresholds (cf. Uhrig-Homburg, 2005), not only in terms of the firm's productivity level but also in terms of the size of the firm's capital stock and existing debt. Figures 1 and 2 summarize the basic properties of the firm's liquidation decision. They present the pay or liquidate decision for different levels of capital and current debt levels, for the average productivity and the highest productivity level respectively. The typical firm that files for liquidation is the one with a low amount of capital stock and/or that is highly indebted. The higher the current debt level the higher the threshold in terms of physical assets that is needed for a firm to decide to continue operating. Furthermore, comparing Figures 1 and 2, another pattern is confirmed: firms with lower productivity level are more likely to file for liquidation

\section{Bond Price Schedule}

As mentioned before, the main reason for firm to file for bankruptcy in the model economy is its inability to cover the payment of its existing debt and fixed cost of operations using the contracts being offered to it. Figure 3 presents the schedule of prices offered to a firm with zero existing debt and being at the average productivity level. Driven by the higher probability of default next period, small firms (with zero physical assets) are charged a higher interest rate. On the other hand, large firms (highest value on the grid, equivalent to 4 times the average incumbent size from the benchmark model) are offered contracts that, for small loan amounts, only reflect the possibility of disruption, i.e. up to level 3.9 in the graph. For larger amounts, however, even large firms face the probability of facing detrimental productivity shocks low enough to induce them to file for bankruptcy, notwithstanding having a positive capital stock.

Bond price schedules give only a partial view, however. It is also important to consider the amount of effective financing a firm can obtain when asking for a loan of a given size $b^{\prime}$. Figure 4 presents the amount of financing today that a firm with zero existing debt and average productivity level obtains for every possible loan size, that is $q\left(x, b^{\prime}\right) b^{\prime}$. As the nominal size of the loan increases so does the probability that the firm will not be able to pay back in the next period. In fact, the lender may adjust the price in a way that the amount of money received today could be larger if the firm asked for a smaller loan. The dashed lines in the graph show the largest size of a loan that a rational firm will ask for; exceeding that threshold will only increase the next period's payment without providing any extra benefit. In the figure large firms could access up to three times the financing than small firms. Endogenous borrowing limits emerge from the model's mechanism. 
The interest rate premium charged to small firms is also present if we classify firms by their productivity level or current debt level. Low productivity firms and highly indebted firms are offered lower bond prices and smaller amount of effective financing, ceteris paribus.

\section{Firm Dynamics}

Limited access to financing obstructs the firms start-up process specially at low and medium level of productivity; if a firm is hit by a good productivity shock it might reach the first best level of capital and evolve practically as being unrestricted from that point on. In Figure 5, I simulate the evolution of a firm that starts at year 1 with no physical assets with no existing debt and at the average productivity level. ${ }^{8}$ As a reference I include the first best level of capital: the level of capital that results from the standard Euler equation proper of models in which firms face no financial restrictions, equation (18). Given the correlation of the shocks, it could be useful to think of the first best as also tracing down the level of the realized productivity shocks.

$$
1=\beta E\left[(1-\tau)\left(z \alpha k^{\alpha-1}+(1-\delta)\right) \mid z\right]
$$

The financial friction imposed by the mechanism of this model affects this prototypical firm in its early years mostly. This pattern is consistent with the finding in Arellano, Bai and Zhang (2007) where enforcement constraints affect small firms disproportionately.

\section{Comparative Statics}

In order to illustrate the main obstacles imposed by inefficient liquidation procedures, I perform the following experiment. Holding the value of all other parameters constant, the efficiency level $\mu$ is changed from the calibrated value of $25 \%$ to $0 \%$ (perfect efficiency) and to 45 and $81 \%$. The last two values correspond to the lowest efficiency among OECD countries and to the overall lowest efficiency reported in Table 1 respectively. I first present the effects on firms' evolution, followed by the aggregate effects on output and average firm size.

\section{Bond Price Schedules}

Equation (10) establishes a link between the efficiency of the liquidation procedure and the loan contracts offered by the lenders. Consequently, the borrowing limits a

\footnotetext{
${ }^{8}$ Conditional on not being hit by the disruption shock all along.
} 
given firm faces under different procedures change. As an illustration, Figure 6 shows that, a firm with large capital-corresponding to four times the average incumbent size in the benchmark model-zero existing debt and average productivity level, the maximum amount of money it can borrow changes monotonically with the level of efficiency. In particular, the lender adjusts its offering so that in an economy with $\mu=0 \%$ such firm can borrow $33 \%$ more compared to an economy with $\mu=81 \%$.

\section{Firm Dynamics}

Consistent with the changes in the bond prices caused by changes on the liquidation efficiency, Figure 7 shows that firm dynamics would also differ. Here, I exposed each firm to the same sequence of productivity shocks and followed them as if they were living under the four different environments. The evolutions of firms living under $\mu=0 \%$ and $25 \%$ are very similar and a firm operating under $\mu=45 \%$ would take approximately three more years to 'catch up' with the former two. However, the experience of a firm evolving under a highly inefficient bankruptcy code $\mu=81 \%$ is very different; it is characterized by a long period of failed attempts to obtain financing ${ }^{9}$ only interrupted when a sequence of good productivity shocks arrived (around year 41). In summary, these results suggest that to measure the effects of the quality of the bankruptcy procedures we should look in the early stages of firms' lives. In this simulation, after the year 41 the firms look identical.

\section{Aggregate Statistics}

The main result of this section is that the economy-wide consequences of having an inefficient liquidation procedure are not necessarily reflected in the size of the surviving firms but rather in the number (mass) of such firms. A movement from the benchmark case to a perfectly efficient liquidation generates $1.2 \%$ increase in output, while moving to an environment in which the lender barely seizes any assets at all in case of liquidation, decreases output by more than $40 \%$. Beyond the output level, the key statistic to notice is the mass of firms that remained inactive or dormant, especially the group of firms (entrepreneurs) that failed to obtain enough financing to start (or re-start after disruption shocks) operations and will remain inactive in the next period. Almost half of the total mass of firms fell into this category under $\mu=81 \%$. An implication of this analysis is that, while reforms among OECD members generate up to $2.6 \%$ of output gains, countries that currently have highly inefficient procedures stand to gain considerably more.

To understand the quantitative implications of the changes in liquidation efficiency, we should look closely at the entry process. Intuitively, under more limited or

\footnotetext{
${ }^{9}$ To make the simulations comparable, when a firm exited the market endogenously I restarted it with zero capital and zero debt but inheriting the sequence of productivity shocks.
} 
expensive loan contracts (Figure 6), only highly productive firms will manage to start operating. Given the persistent productivity process, they will tend to become larger as they evolve. The results of the simulations supported this mechanism; as the bankruptcy procedure became less efficient the entry productivity thresholds-the minimum level of $z$ such that an inactive firm entered the market-increased (Figure $\left.8^{10}\right)$. On the other hand, given the positive correlation of productivity shocks, highly productive firms will have a larger 'demand' for capital; such demand will face different supplies of loans (Figure 6) depending not only on how likely is the firm to default but also on the expected asset recovery if the firm were to default. The interaction of these two forces govern the entry process.

To further understand the role of the bankruptcy efficiency in the entry process it could be helpful to first consider the determination of the interest rate charged on a given loan of size $b^{\prime}$. Intuitively, new projects, with no contribution from current operating income, would devote a larger fraction of that loan to cover the fixed cost leaving fewer resources for capital formation. Firms with a lower stock of capital in the next period will be more likely to be exposed to productivity shocks low enough to induce them to default on the payment $b^{\prime}$ and file for bankruptcy, so lenders will charge such firms a higher interest rate. In the simulations, this interest rate premium requested from new entrants was such that entrepreneurs with low productivity projects failed to start because they were offered a maximum effective financing (i.e. $\left.\max _{b^{\prime}} q\left(x, b^{\prime}\right) b^{\prime}\right)$ lower than the fixed cost. In an environment with no risk of default, the efficiency of the process followed after default would be of minor significance. In contrast, given that in my model new entrants are particularly likely to file for bankruptcy in the immediate future, changes in bankruptcy efficiency affects them the most.

Recent empirical studies provide partial support to the two main findings of this paper: 1) the potentially negative relation between the average firm size and the efficiency of the liquidation procedure, and, 2) the particularly strong effect of such efficiency on the entry process. Aghion, Fally, Scarpetta (2007) study the role of financial development in both entry rates and post-entry growth rates among industrialized and emerging economies. They find that financial constraints affect the entry of small firms the most. In fact, the length of the bankruptcy procedures is among the instrumental variables they use (besides overall measures of contract enforcement and creditor rights) to control for the endogeneity of financial development. They also find that conditional on entry, firm growth is affected by the level of financial development. Furthermore, Desai, Gompers, Lerner (2003) using a sample of European countries find a positive relation between interference of courts ("whether courts are fair and impartial") and average firm size. They find the relation to be particularly strong for less developed countries. In this context, my paper presents a particular mechanism through which the institutional or legal development of a country affects firms size, entry (Figure 8), and post-entry growth (Figure 7).

\footnotetext{
${ }^{10}$ The productivity distribution of entrants for $\mu=45 \%$ and $\mu=25 \%$ were identical.
} 
These empirical studies, however, may be giving a partial view. Given the important role that bankruptcy efficiency plays on financing start-up projects, drawing conclusions from datasets of existing firms must be done with caution. As Figure 9 shows, an analysis focused on the distribution of existing firms (incumbents) generated from the model economy would find that the distribution under $\mu=81 \%$ dominates, in the first order stochastic sense, the distribution generated from an an environment with $\mu=0 \%$. The observed higher average firm size would be, however, misleading. The former environment would have a large mass of entrepreneurs failing to start-up their projects.

To further illustrate the differences in firms' characteristics under the four scenarios, I performed a pseudo-survey that asks firms: 'how restricted are your investment plans?' In particular, I determine if their capital policy function $g^{k}(x)$ corresponds to the First Best as in equation (18). Among the firms that managed to finance their operation $70 \%$ would be labeled unrestricted under the scenario $\mu=81 \%$, while only $51.4 \%$ would be labeled as such under $\mu=0 \%$. The message obtained from this exercise confirms the previous finding; the main effect of inefficient bankruptcy procedures is on limiting the mass of firms obtaining financing (extensive margin). If we were to focus on the characteristics of such firms (intensive margin) it would be tempting to conclude that environments with less efficient legal procedures $\mu=81 \%$ generate less investment obstacles (Table 5).

\section{Concluding Remarks}

This paper presented a simple model of firm dynamics in which the efficiency of the bankruptcy laws was summarized as the fraction of assets that survive the legal procedures, and where borrowing limits arose endogenously under perfect information and complete enforcement. My framework could be extended in several directions. One promising area of research studies the interaction of financial frictions with the occupational choice of entrepreneurs; that is, the outside option that here was normalized to zero, could include the alternative to invest in other sectors and/or to become a worker instead of an entrepreneur. Smith and Wang (2006) develop a model in which financial frictions arise from asymmetric information and where individuals consider the available financing opportunities in their decision to become workers or to start a new project. Furthermore, moving away from stationary equilibria could help understand better the role of the legal framework in the evolution of emerging economies (cf. Desai, Gompers, Lerner, 2003). Buera, Shin (2007) consider the role of financial constraints-modeled as an exogenous borrowing limit-in the transition toward the steady state. They find that the changes in (steady state) output caused by the financial frictions are small but that such frictions can have important consequences for the speed of convergence.

Debt is an important source for firms to finance their investment and growth plans, but its existence depends on the ability of lenders to exercise the contract, and in 
case of default, on the efficiency of the liquidation procedure. In this study, I have focused on the latter. The empirical literature has emphasized the role of the legal system as limiting the size of the firms operating in a country (e.g. Kumar, Rajan and Zingales, 1999). A central message of my paper is that average firm size should not be the only indicator to consider. Simulations for the Mexican manufacturing sector show that bankruptcy procedures that, by definition are constructed to deal with the firms' exit process, could have important consequences for the entry process as well. The potential gains, in terms of output level, of reforming bankruptcy codes would not necessarily come from allowing the existing firms to grow further. The gains may very well come from allowing currently inexistent projects to be undertaken; in other words, the gains may come from the missing firms. 


\section{References}

Aghion, P., Fally, T., Scarpetta,S., 2007. Credit Constraints as a barrier to the entry and post-entry growth of firms, Mimeo

Albuquerque, R., Hopenhayn, H.A., 2004. Optimal lending contracts and firm dynamics. Review of Economic Studies 71, 285-315

Arellano, C., 2008. Default risk and income fluctuations in emerging economies, American Economic Review 98, 690-712

—, Bai, Y., Zhang, J., 2007. Enforcement, incomplete contracts, and firm dynamics. Mimeo

Barletsman, E., Haltiwanger, J., Scarpetta, S, 2004. Microeconomic Evidence of Creative Destruction in Industrial and Developing Countries, Tinbergen Institute Discussion Paper, TI 2004-114/3

Bayer, C., 2006. Investment dynamics with fixed capital adjustment cost and capital market imperfections. Journal of Monetary Economics 53, 1909-1947

Beck, T., Demirguc-Kunt, A., Laeven, L., Levine, R., 2007. Finance, Firm Size, and Growth. Mimeo

—., Levine,R., 2005. Law and Firms' Access to Finance, American Law and Economics Review 7, 211-252

Beck, T., Demirguc-Kunt, A., Maksimovic, V., 2003. Financial and Legal Institutions and Firm Size, World Bank Policy Research Working Paper 2997

—, 2005. Financial and Legal Constraints to Growth: Does Firm Size Matter?, The Journal of Finance 60, 137-177

Buera, F., Shin, Y., 2007. Financial Frictions and the Persistence of History: A Quantitative Exploration. Mimeo

Clementi, G.L., Hopenhayn, H.A., 2006. A theory of financing constraints and firm dynamics. Quarterly Journal of Economics 112, 229-265

Cooley, T., Marimon, R., Quadrini, V., 2004. Aggregate consequences of limited contract enforceability. Journal of Political Economy 112, 817-847

-, Quadrini, V., 2001. Financial markets and firm dynamics. American Economic Review 91, 1286-1310

Dadydenko, S. A., Franks, J. R., 2006. Do bankruptcy codes matter? A study of defaults in France, Germany and the UK. Mimeo 
Desai, M., Gompers, P., Lerner, J., 2003. Institutions, Capital Constraints and Entrepreneurial Firm Dynamics: Evidence from Europe. NBER Working Paper 10165

Djankov, S., Hart, O., McLiesh, C., Shleifer, A., 2006. Debt enforcement around the world. Mimeo

Franks, J., Sussman, O., 2005. Financial innovations and corporate bankruptcy. Journal of Financial Intermediation 14, 283-317

Hart, O., 2000. Different approaches to bankruptcy. NBER Working Papers, W7921

Heer, B., Maußner, A., 2005. Dynamic general equilibrium modelling, Springer

Hennessy, C., Whited, T., 2007. How costly is external financing? evidence from structural estimation. Journal of Finance 62, 1705-1745

Hopenhayn, H. A., 1992. Entry, exit and firm dynamics in long run equilibrium. Econometrica 60, 1127-1150

Hubbard, R. G., 1998. Capital-market imperfections and investment. Journal of Economic Literature 36, 193-225

Kumar, K., Rajan, R., Zingales,L., 1999. What determines Firm Size? NBER Working Paper No. 7208

Levine, R., 1998. The Legal Environment, Banks, and Long-Run Economic Growth. Journal of Money, Credit and Banking 30, 596-613

Smith, A., Wang, C., 2006. Dynamic Credit Relationships in General Equilibrium. Journal of Monetary Economics 53, 847-877

Uhrig-Homburg, M., 2005. Cash-flow shortage as an endogenous bankruptcy reason. Journal of Banking \& Finance 29, 1509-1534

Whited, T., 2006. External finance constraints and the intertemporal pattern of intermittent investment. Journal of Financial Economics 81, 467-502

World Bank, 2007, Closing a Business Database. http://www.doingbusiness.org 
Table A.1. Bankruptcy Efficiency for OECD members

\begin{tabular}{lclc}
\hline Country & Fraction of assets lost $\mu$ & Country & Fraction of assets lost $\mu$ \\
\hline \hline Norway & 0.05 & France & 0.17 \\
Japan & 0.06 & Denmark & 0.17 \\
Canada & 0.07 & Greece & 0.17 \\
Belgium & 0.08 & Portugal & 0.17 \\
Finland & 0.08 & Sweden & 0.17 \\
Iceland & 0.08 & Spain & 0.19 \\
Netherlands & 0.09 & Austria & 0.22 \\
Korea & 0.10 & Hungary & 0.22 \\
United Kingdom & 0.10 & Mexico & 0.25 \\
Ireland & 0.11 & Italy & 0.26 \\
Australia & 0.12 & Turkey & 0.30 \\
New Zealand & 0.12 & Slovakia & 0.33 \\
Germany & 0.13 & Poland & 0.33 \\
United States & 0.14 & Czech Republic & 0.45 \\
Switzerland & 0.17 & Luxembourg & N/A \\
& Source: World Bank (2007) and author calculations \\
\hline
\end{tabular}


Table 1. Bankruptcy Efficiency and Financial Constraints

\begin{tabular}{lccc}
\hline Country & Fraction of Assets Lost $\mu$ & Financial Obstacle & Legal Obstacle \\
\hline \hline OECD & & & \\
Canada & 0.07 & 2.11 & 1.46 \\
Czech Republic & 0.45 & 3.17 & 2.18 \\
France & 0.17 & 2.75 & 1.81 \\
Germany & 0.13 & 2.60 & 2.14 \\
Hungary & 0.22 & 2.61 & 1.30 \\
Italy & 0.26 & 1.98 & 2.27 \\
Mexico & 0.25 & 3.51 & 2.94 \\
Poland & 0.33 & 2.48 & 2.32 \\
Portugal & 0.17 & 1.82 & 1.86 \\
Slovakia & 0.33 & 3.38 & 2.08 \\
Spain & 0.19 & 2.22 & 1.97 \\
Sweden & 0.17 & 1.85 & 1.49 \\
Turkey & 0.30 & 3.11 & 2.28 \\
United Kingdom & 0.10 & 2.21 & 1.51 \\
United States & 0.14 & 2.39 & 1.79 \\
Lowest & & & \\
Lao PDR & 0.81 & & 0.59 \\
Correlation & 1.00 & and author calculations
\end{tabular}

Table 2. Parameter Values

\begin{tabular}{lcc}
\hline \multicolumn{1}{c}{ Parameter } & Symbol & Value \\
\hline \hline Decreasing returns parameter & $\alpha$ & 0.3 \\
Discount factor & $\beta$ & 0.95 \\
Depreciation rate & $\delta$ & 0.05 \\
Interest rate & $r$ & 0.05 \\
Productivity autocorrelation & $\rho_{z}$ & 0.44 \\
Productivity standard deviation & $\sigma_{z}$ & 0.71 \\
Disruption probability & $\tau$ & 0.05 \\
Bankruptcy efficiency & $\mu$ & 0.25 \\
Fixed cost & $f$ & 0.3 \\
\hline
\end{tabular}

Table 3. Calibration

\begin{tabular}{cccc}
\hline Parameter & Value & Target & Benchmark model $(\mu=25 \%)$ \\
\hline \hline$f$ & 0.3 & Relative size of entrants 0.3 & 0.31 \\
$\sigma_{Z}$ & $0.71^{11}$ & Exit rate $7 \%^{12}$ & $7.56 \%$ \\
\hline
\end{tabular}


Table 4. Comparative Statics

\begin{tabular}{ccccc} 
Statistic & $\boldsymbol{\mu}=\mathbf{8 1} \%$ & $\boldsymbol{\mu}=\mathbf{4 5} \%$ & $\boldsymbol{\mu}=\mathbf{2 5} \%$ & $\boldsymbol{\mu}=\mathbf{0} \%$ \\
\hline \hline Aggregate Output $\left(Y^{13}\right)$ & 58.4 & 97.5 & 98.8 & 100 \\
Average Incumbent Firm Size & 3.51 & 3.09 & 3.13 & 3.11 \\
Mass of Inactive Firms $(k=0)$ & 52.1 & 12.5 & 11.9 & 10.0 \\
Entering & 3.5 & 7.4 & 7.0 & 7.6 \\
Not Entering & 48.6 & 5.2 & 4.9 & 2.4 \\
\hline
\end{tabular}

Table 5. Bankruptcy Efficiency and Financial Frictions

\begin{tabular}{ccccc}
\hline Statistic & $\boldsymbol{\mu}=\mathbf{8 1} \%$ & $\boldsymbol{\mu}=\mathbf{4 5} \%$ & $\boldsymbol{\mu}=\mathbf{2 5} \%$ & $\boldsymbol{\mu}=\mathbf{0} \%$ \\
\hline \hline Mass of firms with access to financing & $50.5 \%$ & $92.1 \%$ & $92.7 \%$ & $94.7 \%$ \\
Fraction at First Best & 69.9 & 50.9 & 51.7 & 51.4 \\
\hline
\end{tabular}


Figure 1. Liquidation Decision, Average Productivity

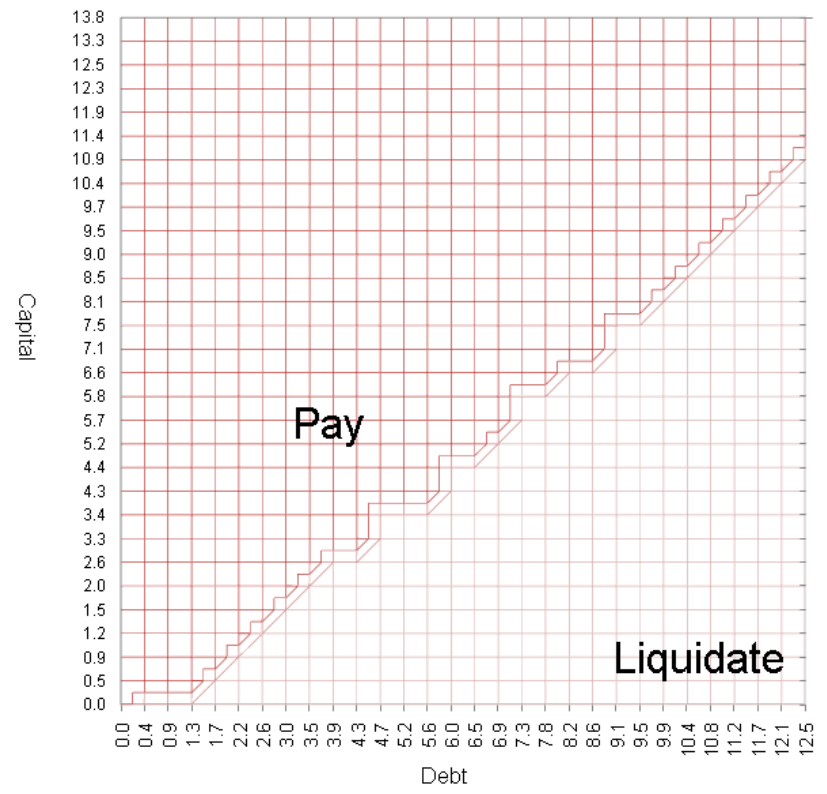

Figure 2. Liquidation Decision, High productivity Productivity

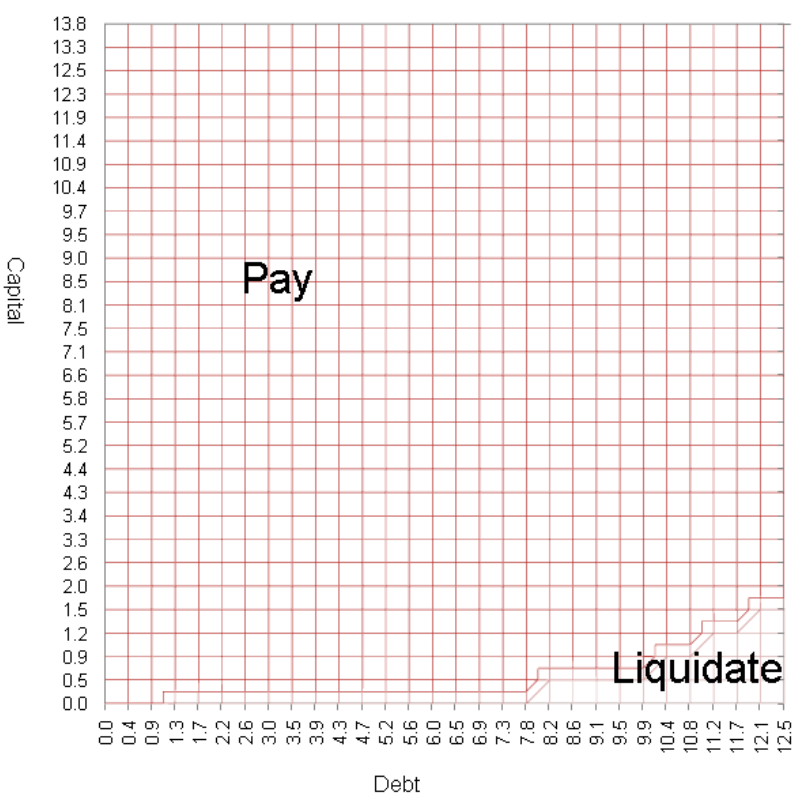


Figure 3. Bond Prices for Large and Small Firms

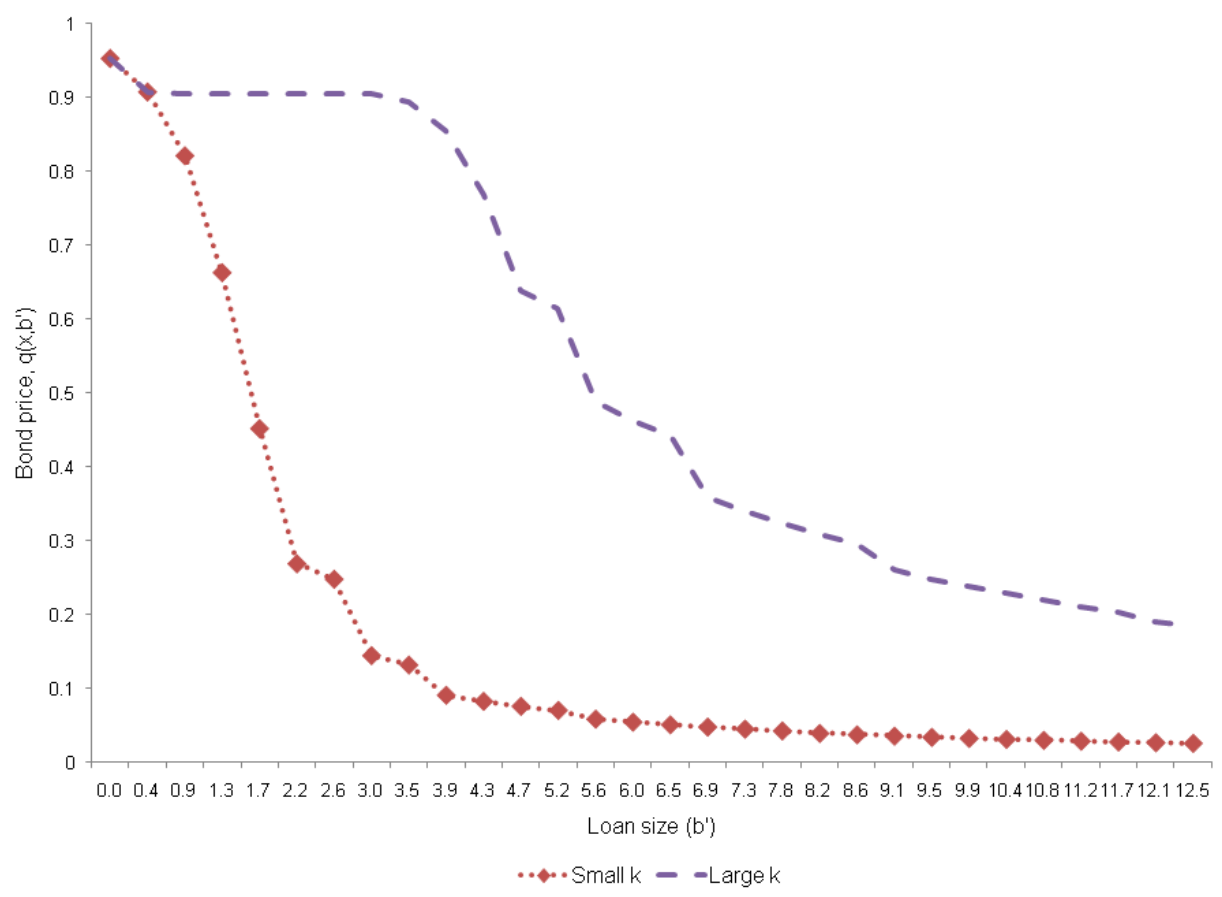

Figure 4. Effective Financing for Large and Small Firms

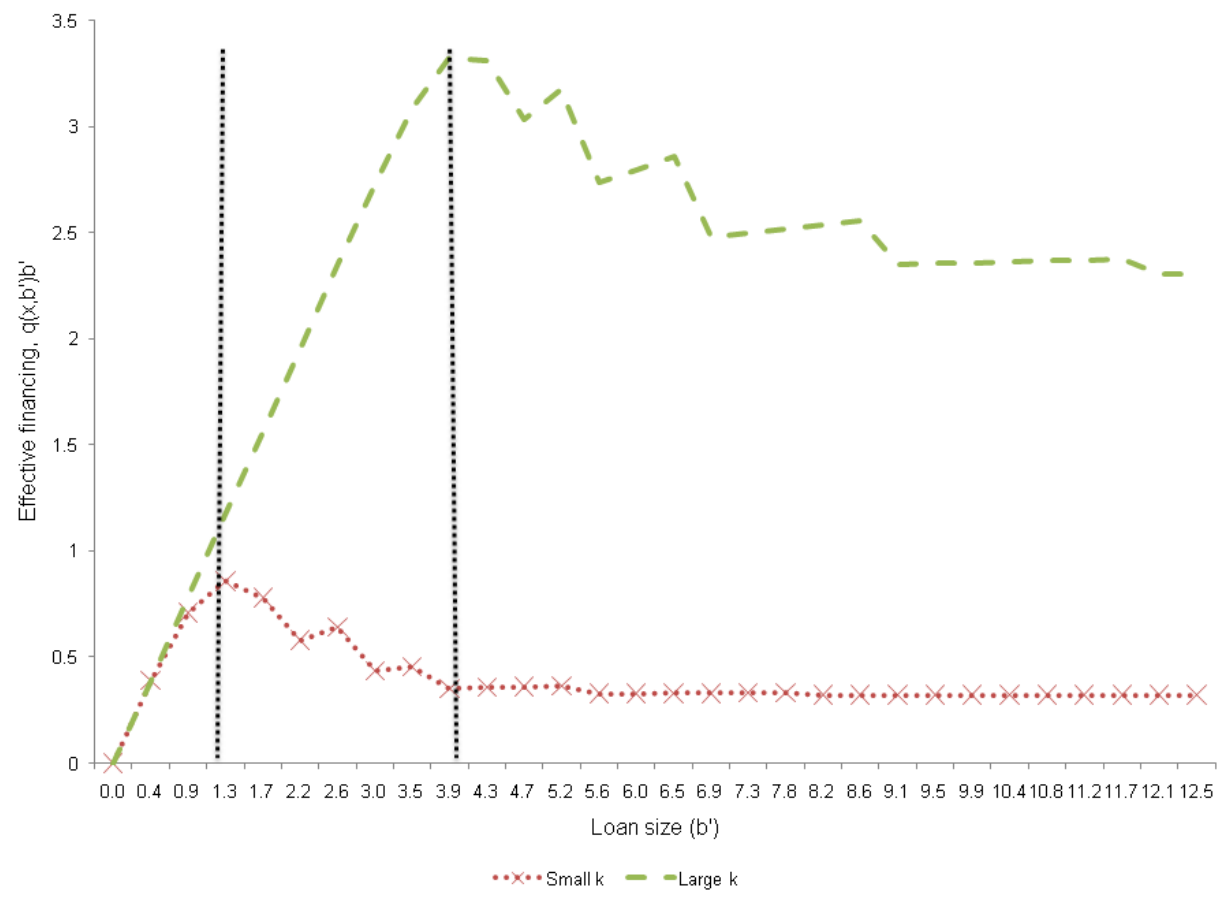


Figure 5. Firm Dynamics Benchmark and First Best

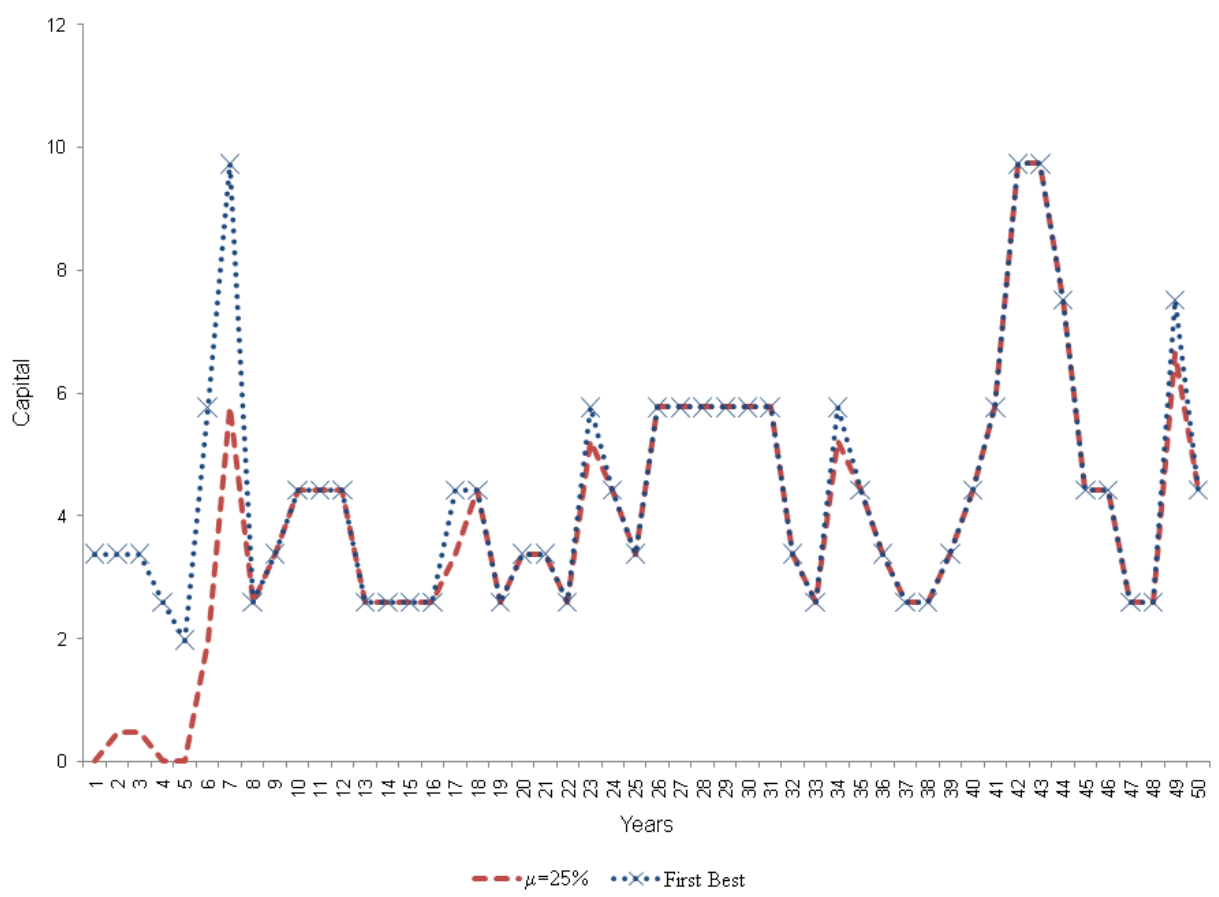

Figure 6. Effective Financing and Bankruptcy Efficiency

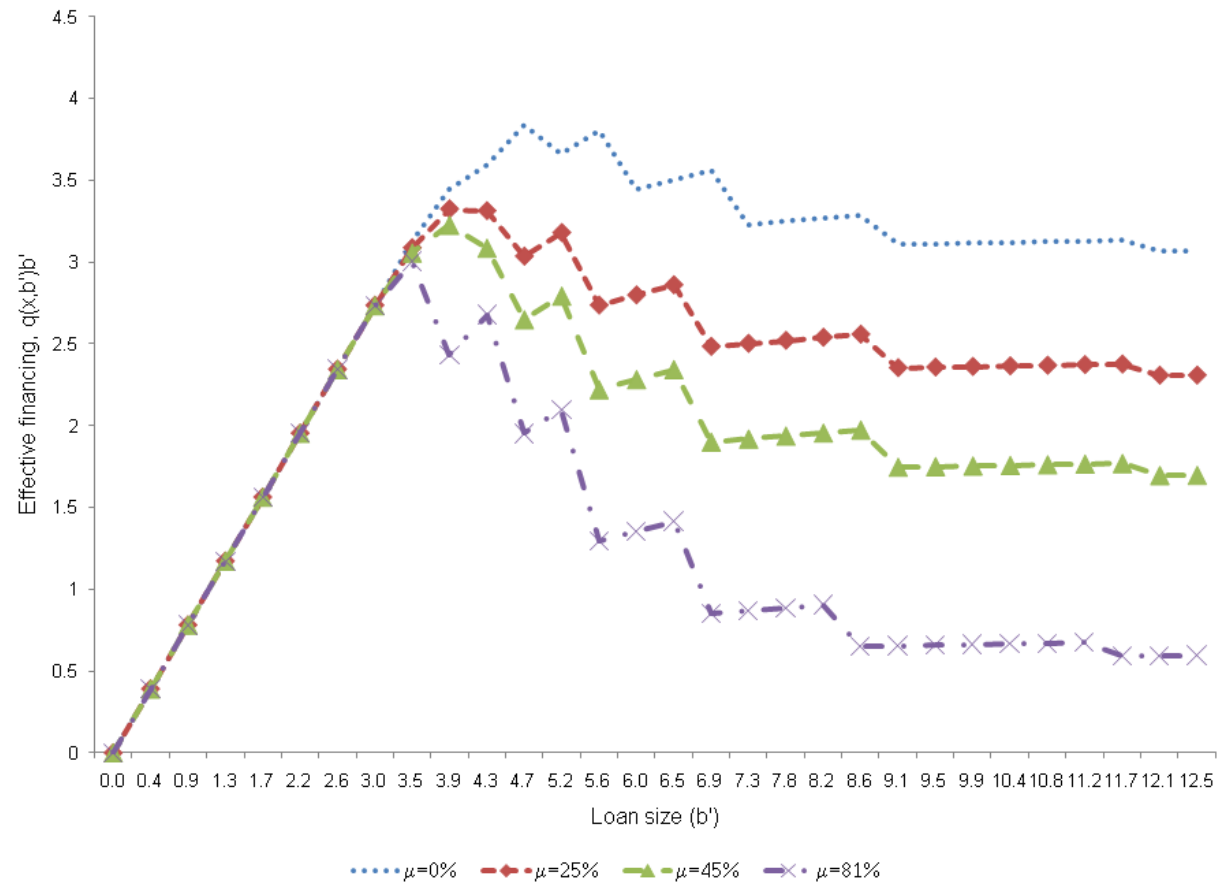


Figure 7. Firm Dynamics and Bankruptcy Efficiency

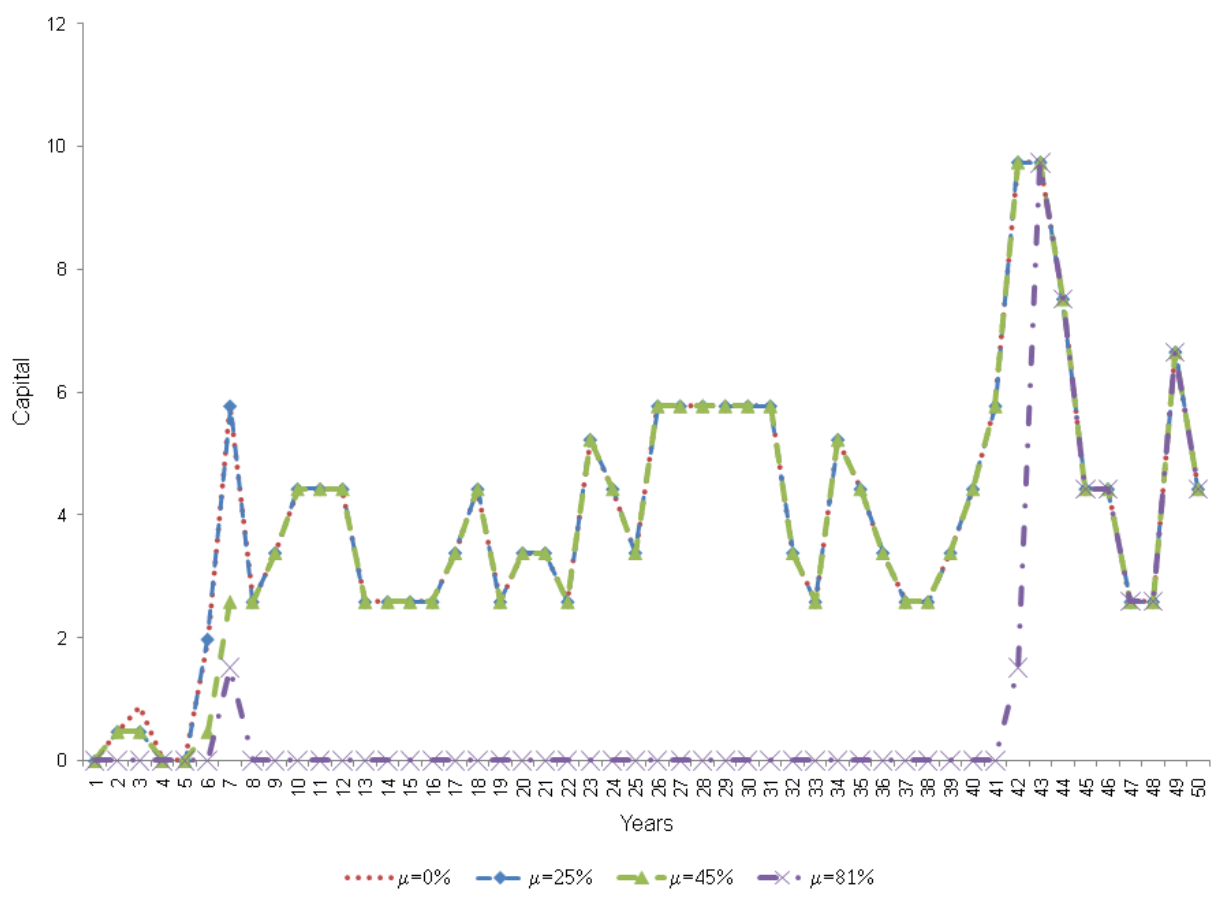

Figure 8. Entrants Productivity Distribution

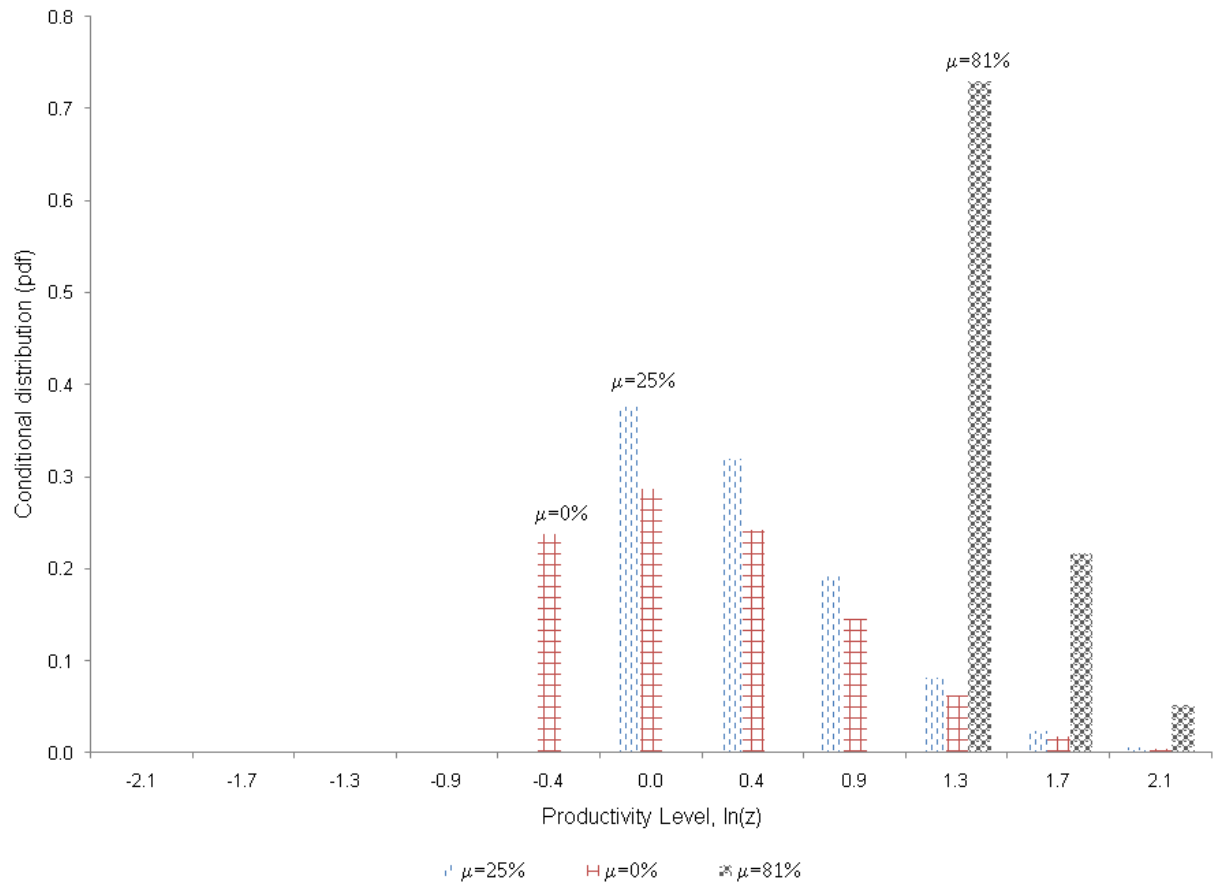


Figure 9. Firm Size Distribution and Bankruptcy Efficiency

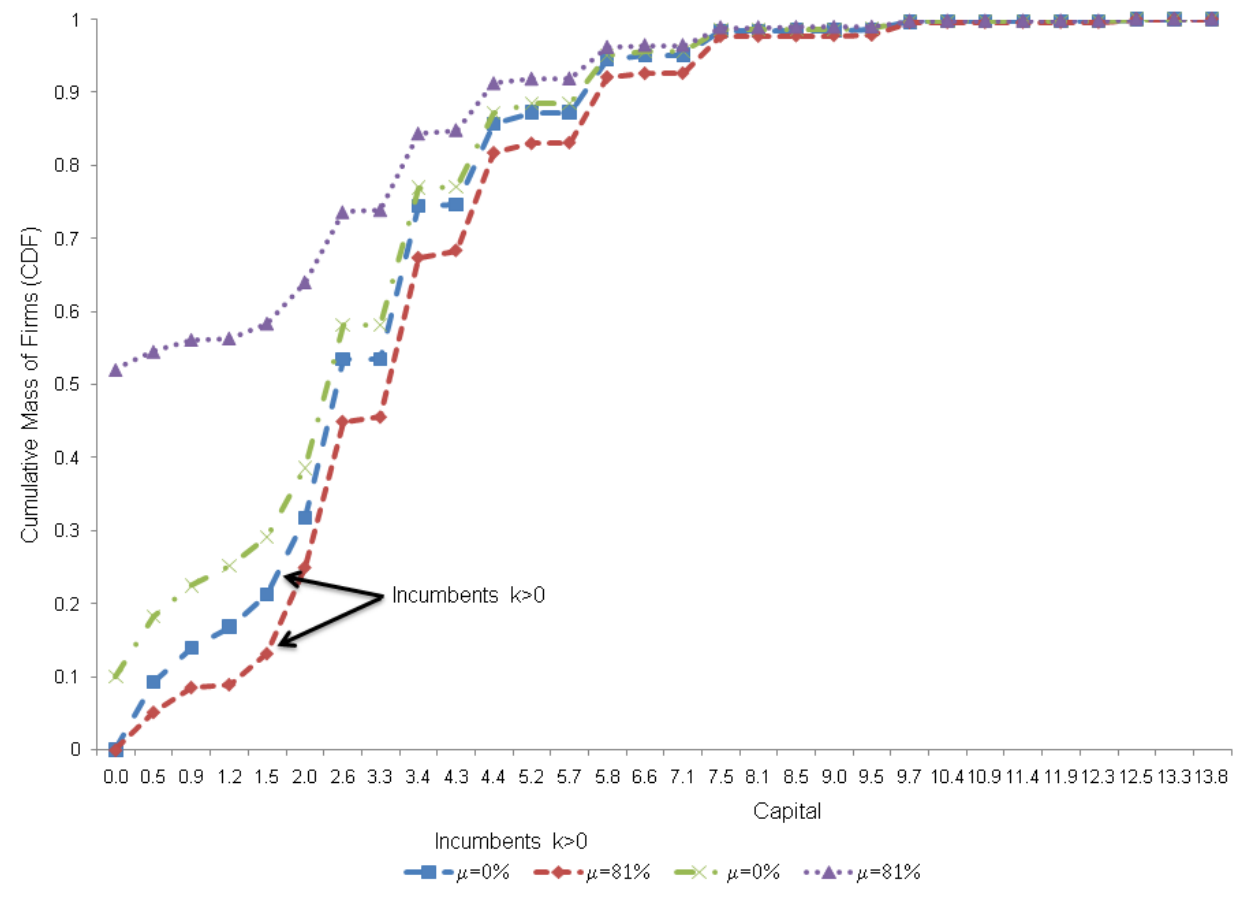

